Journal of Social Sciences (COES\&RJ-JSS)

ISSN (E): 2305-9249 ISSN (P): 2305-9494

Publisher: Centre of Excellence for Scientific \& Research Journalism, COES\&RJ LLC

Online Publication Date: $1^{\text {st }}$ October 2016

Online Issue: Volume 5, Number 4, October 2016

https://doi.org/10.25255/jss.2016.5.4.606.620

\title{
Management of facilities and infrastructures at one roof schools: A Multicase Study at One Roof Public Primary and Middle Schools and Islamic Primary and Middle Schools in East Java
}

\author{
${ }^{1}$ Idris, ${ }^{2}$ Nurul Ulfatin, ${ }^{3}$ Ahmad Sonhaji K.H, sImron Arifin
}

${ }^{1}$ Candidate of Doctorate in Management education, State University of Malang ${ }^{2}$ Professor in Management education, Post Graduate Program, State University of Malang 3Professor in Management education, Post Graduate Program, State University of Malang \&Senior Lecturer, Doctorate in Management education, Post Graduate Program, State University of Malang, Indonesia

\begin{abstract}
:
This research was aimed at describing the management of facilities and infrastructure at one roof public primary and middle schools as wel as Islamic primary and middle schools in East Java. This research employed the qualitative approach with multi sites design. The location of this research was in three one roof schools. Data was collected by using interview, observation, and documentation. The researcher was the main key instrument. The analysis was done by employing individual analysis within each case and cross case analysis among the three cases. Results of this research showed that the management of facilities and infrastructures among the one roof public primary and middle schools and islamic primary and middle schools vary in planning, usage, supervision, and abolition.

Keywords:

Management of facilities and infrustructures, One roof schools, State public primary and middle school, and islamic primary and middle schools

Citation:

Idris, Ulfatin, Nurul; Ahmad, Sonhaji K.H.; Arifin, Imron; (2016); Management of facilities and infrastructures at one roof schools: A Multicase Study at One Roof Public Primary and Middle Schools and Islamic Primary and Middle Schools in East Java; Journal of Social Sciences (COES\&RJ-JSS), Vol.5, No.4, pp: 606-620; https://doi.org/10.25255/jss.2016.5.4.606.620.
\end{abstract}




\section{Intgroduction}

One roof schools are those developed as the governmental policy to succeed the oblighted 9 years basic education in Indonesia. This has been aimed at all children within 13-15 years of age who graduate from public and islamic primary schools from various isolated areas due to the geographical area can be absorbed in middle schools. Generally in the isolated and sprawl areas, there have not been middle schools being managed to build for children. If only there is one, this usually is not reachable by the graduates of primary schools in such areas. This can happen due to the limited numbers of the primary school graduates from the areas. Therefore, the establisment of new middle schools are also limited. The new establisment of middle schools are seen as not efficient in terms of the funding and human resource supports. Meanwhile, there have been some areas having low index participation of education for middle schools due to having no adequate schooling services. This gives ideas of establishing the so-called one roof schools.

The one roof schools are educational institution operating education covering integrated primary and middle schools. The integration can be in the forms of phisical and management matters. The integrated phisical matter concerns with the integrated location for both primary and middle schools. The integrated management means that the management of the integrated location include integration in (a) the development of basic education vision and mission, (b) formulation of annual school programs, (c) management of new students enrolement, and (d) efforts in managing the numbers of drop outs, repeating, and transition by using cohort analysis, (e) efforts to manage the needs for educators, (f) efforts to manage the needs for facilities and infrastructures, and (g) basic education quality development.

The one roof school operation is expected to comply the needs for educational equalization service access. In fact, there still have problems in practice. Surya (2010:1) states that based on the monitoring in such schools, it has been found out that their readiness is being forced resulting the needs for improving the human resources and facilities as well as infrastructures. The obvious problems concern the limited supporting aspects for the good educsational management. The decree of the Indonesia Republic Government no 32, 2013 regulating the National Education Standard, chapter, verse 1 strongly mandates to manage educational standard covering content standard, process standard, graduate competence standard, teachers and educational staff standard, facilities and infrastructure standard, management standard, budgetting standard, and evaluating standard. The education operation, thus, must comply the 8 National Education Standards by law as the realiation of the educational wuality attainment. Such message has been enforced with the governmental regulation no 32, 2013 chapter 3 describing that National Education Standard functions as the foundation of educational planning, actuating, and controlling to consummate the excellent national education. Therefore, each of the educational institution is oblighted to operate the educational processes on the basis of those standards.

Facilities and Infrastructures are parts of the standards to be complied. In the context of the one-roof schools, these are important and crucial aspects to be managed. Considering that such schools are esteblished to integrate prrimary and middle schools at the same time, the facilities and infrastructure play important roles in the schools operation. Facilities and insfrastructures are the supporting components to ensure the smoootness of teaching and learning processes. Matin and Fuad (2014:1) say that facilities and 
infrastructures are one of the important to support the learning process at schools. The success of education at schools are influenced by the condition and completeness of the facilities and infrastructures as well as their optimum usage.

There have been some one roof schools in Sidoarjo and Surabaya. Based on the preliminary research, the researcher found out that there have been unique one roof schools named (1) the state public primary school of Sidotopo IV (SDN Sidotopo IV) integrated with the state public middle school of Surabaya 44 (SMPN 44 Surabaya), East Java, Indonesia , (2) state public primary school of Sawohan II (SDN Sawohan II) integrated with state public middle school of Buduran, Sidoarjo, East Java, Indonesia, and (3) the one roof islamic private primary school "Nurul Huda" (MI Nurul Huda) integrated with the islamic private middle school "Nurul Huda" (MTs Nuru Huda) in Sedatim Sidoarjo, East Java, Indonesia.. The uniqeness of these schools are two folds, first it concerns with the differences of the state and private school status and second, it concerns the operational concepts which include the differences in managing facilities and infrastructures. These three schools have different cases.

The main focus of this research was the management of facilities and infrastructures of the one roof state public primary and middle schools and the one roof private islamic primary and middle schools in East Java, Indonesia. This fouce was elaborated to be sub focus as follows: (1) planning of the facilities and infrastructures, () usage of facilities and infrastructures, and (3) controlling and abolition of the facilities and infrastructures.

\section{Research Method}

This research employed qualitative approach by multisite case study design at three oneroof schools, which were the state public pramy school of Sidotopo IV (SDN Sidotopo IV) integrated with the state middle school of 4 Surabaya (SMP N 4 Surabaya), the state public pramy school of Sawohan II (SDN Sawohan II) integrated with the state middle school of 4 Buduran Sidoarjo (SMPN Buduran Sidoarjo), East Java, Indonesia, and the islamic private primary school of "Nurul Huda" (MI Nurul Huda) integrated with the private islamic middle school of "Nurul Huda" (MTs Nurul Huda) in Sedati, Sidoarjo, East Java, Indinesia. The multicases design of this research suited the characteristics of these schools differences as follows:

Table 1 Differences of Research Location

\begin{tabular}{cclll}
\hline No & Components & \multicolumn{3}{c}{ One Roof Schools } \\
\cline { 3 - 5 } & & SD Negeri & SDN Sawohan II & MI Nurul Huda \\
& Sidotopo IV & integrated with & integrated with \\
& & integrated with & SMP Negeri & MTs Nurul \\
& & SMP Negeri 44 & Sekolah Satu Atap & Huda Sedati \\
& & Surabaya & Buduran Sidoarjo & Sidoarjo \\
\hline 1 & Status & State & State & Private \\
2 & Ministrial & Ministry of & Ministry of & Ministry of \\
& office & National & National & Religion \\
& & Education & Education & \\
3 & Location & Densed & Isolated & Densed \\
& & populated & Community & Populated \\
& housing & & Community \\
& community & & \\
& & & &
\end{tabular}




\begin{tabular}{|c|c|c|c|c|}
\hline 4 & $\begin{array}{l}\text { Facilities and } \\
\text { Insfrastructures } \\
\text { condition }\end{array}$ & $\begin{array}{l}\text { Adequate and } \\
\text { Complete }\end{array}$ & Not adequate & Adequate \\
\hline$J$ & Management & 2 Managers & 1 Manager & 2 Managers \\
\hline 6 & $\begin{array}{l}\text { School } \\
\text { Addresss }\end{array}$ & $\begin{array}{l}\text { Surabaya, East } \\
\text { Java }\end{array}$ & $\begin{array}{l}\text { Sidoarjo, East } \\
\text { Java }\end{array}$ & $\begin{array}{l}\text { Sidoarjo, East } \\
\text { Java }\end{array}$ \\
\hline
\end{tabular}

The data was collected using interview, observation, and documentation. The researcher was the main key instrument. The presence of the researcher in the location of the research was opennly made, which means that the informen knew the presence of the researcher. The data sources of this research were (1) informen, (2) activities or occations, (3) places or locations, (4) objects and pictures, and (5) records, documents, and files.

The data analysis was done in two stages, which were (1) individual analysis within the single and (2) cross case analysis among the multuple cases on the basis of the Yin's (1984) theory. The procedure of analysis refered to Bogdan dan Biklen (1982:13), which were interactive data collection during the collection time and after the collection time by tracking, organiing, selecting, synthesizing, and understanding to seek for patterns, interpreting and presenting the meaning of the phenomenon. Such interactive process folloing the Miles dan Huberman (1992:90) approach comprised the data reduction, presentation, and conclusion.

Steps of the data collection done following the Bogdan and Biklen's (1998) advised which was practices by (1989) included: (1) limiting the study scope, (2) deciding on the kinds of the study, (3) developing analysis inquiry, (4) planning data collection phases by considering the previous mapping, (5) writing observer's comment about the appearing ideas, (6) writing memo to the researcher himself about the studied matters, and (7) exploring relevant liturature sources. To ensure the validity of the data, the researcher followed Moleong's (2006:324) advise on looking at the credibility, transferability, dependability), and confirmability. Of these four types of validity measurements the credibility was prioritized.

\section{Results of the Research}

This research revealed that the management of the facilities and infrastructures of the oneroof schools in East Java vary one among others. There have been similarities and differences among them. Herewith, these are described in detail on the basis of the focus of this research, which are, (1) planning of the facilities and infrastructures, (2) usage of the facilities and infrastructures, and (3) supervision and abolition of the facilities and infrastructures.

a. Planning of the facilities and infrastructures

Planning of the facilities and infrastructures consisted of identification, planning, and provision of the facilities and infrastructures. The three schools had similarities in planning the facilities and infrastructures in terms of (1) forming facilities and infrastructures team and conducting need analysis in identifying the needs of the facilities and infrastructures, (2) the planning design was made in the schools plans and adjusted with the funding ability, (3) the provision was based on the propper and real needs to fulfill for buying. Their differences turned out to be (1) the need identification in case 2 
involved school committee and priority scale; in case 3 it was dine by first doing banchmark in successful school, and (2) in case 1, the planning was discussed woth the school stakholders; in case 1 and 2 , the planning also made by writing proposal submitted to the regional department of education; and in case 3, the planning involved the foundation entities, (3) The provision of the facilities and infrastructures in case 1 and 2 was made by having a cooperation with regional office of the education department and vendors; Meanwhile, in case 3 the provision was obtained by having donation from third parties.

b. The usage of facilities and infrastructures

The usage of the facilitities and insfrastructures in these three schools concerned inventory, storage, and oprimization of the facilities and infrustructures. These showed the tendency of similarities in practice, which were, (1) the inventory was done by recording and coding the goods delivery, (2) the goods storage was done by sorting used goods being stored in the working rooms or units of users, and those aditional as well as damage goods were stored in warehouse, (3) the optimiation of the goods usage was done by using the goods for learning with periodic maintenance.

c. Supervision/Controlling and abolition of the facilities and infrastructures

The supervision or controlling and abolition of the facilities and infrastructures concerned all related aspects of these. These turned out to have similarities among the three schools, which was, the principals supervised and controlled the usage of the facilities and infrastructures. The differences concerned delegation and coordination. In case 1 and 2, the Principals delegated his supervisory or controlling roles to special officers. In case 3, the principal coordinated with the foundation officers.

d. Management of the facilities and infrastructures

Wholistically, the management of facilities and infrastructures in these three schools included the planning, usage, controlling, and abolition dimensions. These can be summaried in Table 2.

Table 2 Findings of the management of facilities and infrastructures in the one-roof state primary and middle schools and privae islamic primary and middle schools in East Java 
Journal of Social Sciences (COES\&RJ-JSS), 5(4), pp. 606-620

\begin{tabular}{|c|c|c|c|c|c|}
\hline & Planning & $\begin{array}{ll}\text { a. } & \text { Conducting } \\
\text { School } \\
\text { Stakeholders } \\
\text { meeting } \\
\text { b. } \\
\text { Conducting } \\
\text { RKAS (School } \\
\text { Budget Need } \\
\text { Plan) } \\
\text { adjustment } \\
\text { c. Doing } \\
\text { Proposal } \\
\text { writing and } \\
\text { submission }\end{array}$ & $\begin{array}{l}\text { a. Making RAB } \\
\text { (Expense Budget } \\
\text { Plan) } \\
\text { b. Conducting } \\
\text { school } \\
\text { community } \\
\text { member meeting } \\
\text { c. Writing and } \\
\text { submitting } \\
\text { proposal to the } \\
\text { regional office of } \\
\text { education }\end{array}$ & $\begin{array}{l}\text { a. Identifyinng } \\
\text { and selecting } \\
\text { needs } \\
\text { b. Conducting } \\
\text { meeting to } \\
\text { discuss the } \\
\text { needs and } \\
\text { budget } \\
\text { availability } \\
\text { c. Conducting } \\
\text { meeting with } \\
\text { the foundation } \\
\text { officers }\end{array}$ & $\begin{array}{l}\text { Similarities: } \\
\text { a. Formulating needs in the } \\
\text { school plan } \\
\text { b. Adjusting needs provision } \\
\text { with the available budget } \\
\text { Differences: } \\
\text { 1. Case } 1 \text { the plan was discussed } \\
\text { in the school stakeholders } \\
\text { meeting } \\
\text { 2. Case } 2 \text { and } 3 \text { writing and } \\
\text { submitting proposal to the } \\
\text { regional education } \\
\text { department office } \\
\text { 3. Case } 3 \text { involving the } \\
\text { foundation members }\end{array}$ \\
\hline & Provision & $\begin{array}{ll}\text { a. Purchasing } \\
\text { b. Cooperating } \\
\text { with the } \\
\text { Regional } \\
\text { Education } \\
\text { Department } \\
\text { c. Cooperating } \\
\text { with vendors } \\
\end{array}$ & $\begin{array}{l}\text { a. Purchasing } \\
\text { b. Cooperating with } \\
\text { the Regional } \\
\text { Education } \\
\text { Department } \\
\text { c. Cooperating with } \\
\text { vendors }\end{array}$ & $\begin{array}{l}\text { a. Purchasing on } \\
\text { the basis of } \\
\text { the needs } \\
\text { b. Having } \\
\text { donation from } \\
\text { third parties }\end{array}$ & $\begin{array}{l}\text { Similarities: } \\
\text { Provision by purchasing } \\
\text { Differences: } \\
\text { d. Case } 1 \text { and } 2 \text { Cooperating } \\
\text { with the Regional Education } \\
\text { Department and Vendors } \\
\text { e. Case } 3 \text { accepting donation } \\
\text { from third parties }\end{array}$ \\
\hline \multirow[t]{3}{*}{ Usage } & Inventory & $\begin{array}{l}\text { a. Receiving } \\
\text { Delivery } \\
\text { b. Coding }\end{array}$ & $\begin{array}{l}\text { a. Recording } \\
\text { incoming delivery } \\
\text { b. Coding }\end{array}$ & $\begin{array}{ll}\text { a. Receiving } \\
\text { Delivery } \\
\text { b. Coding } \\
\end{array}$ & $\begin{array}{l}\text { a. Receiving Delivery } \\
\text { b. Coding }\end{array}$ \\
\hline & Storage & $\begin{array}{l}\text { a. Used goods } \\
\text { were stored in } \\
\text { working rooms } \\
\text { b. Unused and } \\
\text { damage goods } \\
\text { were stored in } \\
\text { Wherehouse }\end{array}$ & $\begin{array}{l}\text { a. Goods were } \\
\text { strored on the } \\
\text { basis of their } \\
\text { characteristics } \\
\text { b. Goods were } \\
\text { handed over to } \\
\text { wprking units } \\
\text { c. Unused goods } \\
\text { were stored in } \\
\text { wherehouse }\end{array}$ & $\begin{array}{l}\text { a. Used goods } \\
\text { were stored } \\
\text { in working } \\
\text { rooms } \\
\text { b. Unused and } \\
\text { damage } \\
\text { goods were } \\
\text { stored in } \\
\text { Wherehouse }\end{array}$ & $\begin{array}{l}\text { a. Used goods were stored in } \\
\text { working rooms } \\
\text { b. Unused and damage goods } \\
\text { were stored in Wherehouse }\end{array}$ \\
\hline & $\begin{array}{l}\text { Usage } \\
\text { optimization }\end{array}$ & $\begin{array}{l}\text { a. Utilized by } \\
\text { teachers and } \\
\text { students in } \\
\text { learning } \\
\text { b. Maintenance }\end{array}$ & $\begin{array}{l}\text { a. Utilized by } \\
\text { teachers and } \\
\text { students in } \\
\text { learning } \\
\text { b. Periodical Check }\end{array}$ & $\begin{array}{l}\text { a. Utilied by } \\
\text { teachers and } \\
\text { students in } \\
\text { learning } \\
\text { b. Maintenance }\end{array}$ & $\begin{array}{l}\text { a. Utilized bu teachers and } \\
\text { students in learning } \\
\text { b. Maintenance }\end{array}$ \\
\hline \multirow[t]{2}{*}{$\begin{array}{l}\text { Supervision/ } \\
\text { Controlling } \\
\text { and Abolition }\end{array}$} & $\begin{array}{l}\text { Supervision/ } \\
\text { Controlling }\end{array}$ & $\begin{array}{l}\text { Principal assigned } \\
\text { aditional tasks } \\
\text { to identified } \\
\text { teachers } \\
\text { (Facility and } \\
\text { Infrustructure } \\
\text { team) }\end{array}$ & $\begin{array}{l}\text { Personal } \\
\text { observation by the } \\
\text { authoried person }\end{array}$ & $\begin{array}{l}\text { Principals } \\
\text { coordinated with } \\
\text { foundation } \\
\text { members }\end{array}$ & 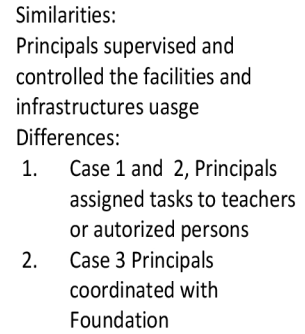 \\
\hline & Abolition & $\begin{array}{l}\text { a. Damage goods } \\
\text { supervision } \\
\text { b. Abolition } \\
\text { c. Reporting to } \\
\text { the local } \\
\text { government } \\
\text { authoeity } \\
\text { d. Warehouse } \\
\text { storage }\end{array}$ & $\begin{array}{l}\text { a. Damage and } \\
\text { lost goods } \\
\text { supervision } \\
\text { b. Abolition by } \\
\text { way of disposal } \\
\text { and burning } \\
\text { c. Reporting to } \\
\text { the related } \\
\text { department }\end{array}$ & $\begin{array}{ll}\text { a. } & \text { Damade } \\
& \text { goods } \\
& \text { supervision } \\
\text { b. } & \text { Abolition } \\
\text { c. Reporting to } & \text { the local } \\
& \text { government } \\
& \text { authority } \\
\text { d. } & \text { Wherehouse } \\
& \text { storage }\end{array}$ & $\begin{array}{l}\text { Similarities: } \\
\text { a. Damage goods supervision } \\
\text { b. Abolition } \\
\text { c. Report to Local government } \\
\text { authority } \\
\text { d. Warehouse storage } \\
\text { Differences: } \\
\text { Not Applicable }\end{array}$ \\
\hline
\end{tabular}


Management of facilities and infrastructures at one roof schools.... 
The management of the facilities and infrastructures at state public primary anc middle schools and private islamic primary and middle schools can be formulated in the following diagram. Feagure 1.
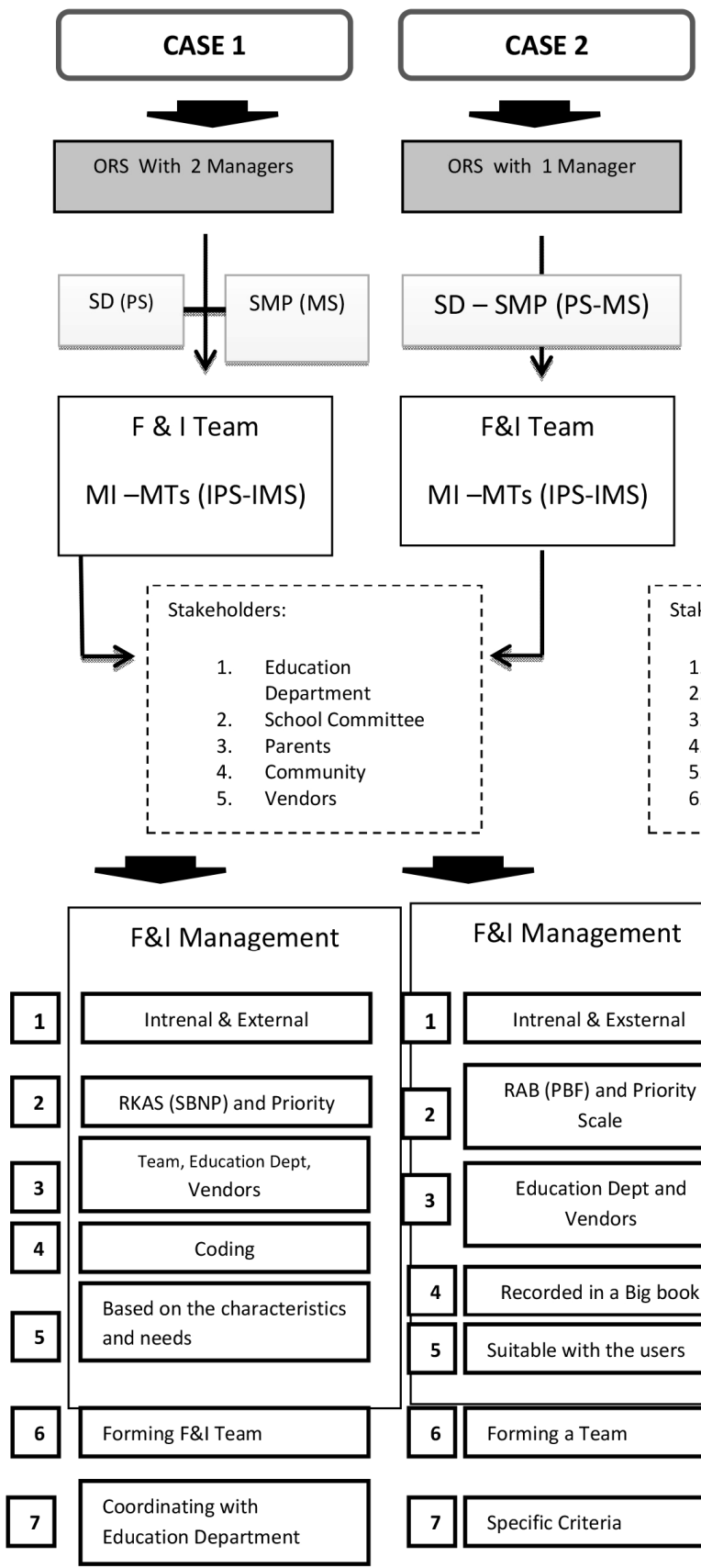

F\&l Management

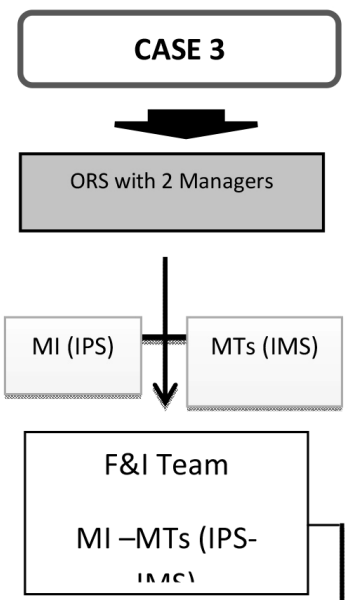

Stakeholders:

Religion Department

2. Foundation

3. School COmmitee

4. Parents

5. Community

6. Vendors

Feagure 1 Management of the facilities and infrustructures at One-Roof state public primary and middle schools and private islamic primary and middle schools in East Java

\begin{tabular}{|c|c|}
\hline 1 & Accelerate and \\
\hline 2 & \multicolumn{1}{|c|}{ Priority Scale } \\
\hline & \\
\hline 3 & Foundation and Vendors \\
\hline 4 & \\
\hline 5 & Pengkodean \\
\hline & \\
\hline 6 & Suitable with users \\
\hline \hline 6 & Routine Supervision \\
\hline 7 & \begin{tabular}{l} 
Coordinating with the \\
\hline
\end{tabular} \\
\hline
\end{tabular}


Management of facilities and infrastructures at one roof schools....

$\begin{array}{ll}\text { SD } & \text { : Sekolah Dasar (Primary School) } \\ \text { PS } & \text { : Primary School } \\ \text { SMP } & \text { : Sekolah Menengah Pertama (Middle School) } \\ \text { MS } & \text { : Middle School } \\ \text { F \& I } & \text { : Facilities and Infrastructures } \\ \text { RKAS/SBNP } & \text { : Rencana Kebutuhan Anggaran Sekolah (School Budget Need Plan) } \\ \text { RAB/PBF } & \text { : Rencana Anggaran Biaya/Funding Budget Plan }\end{array}$

\section{Ducussion}

a. Facilitities and Infrastructure Plan

The aimes of the facilities and infrastructure plan is to know the condition of the quantity and qualities of the need goods for supporting the school operation. There were varies similarities and differences in the three schools facilities and uinfrastructure management procedures. The similarities of having the need identification internally and externally were in line with Depdiknas (2003:21) advised by which such activities were important to do before planning process. Viewed from the theories, the internal condition concerned with the academic and non academic needs; meanwhile, the external condition concerned with the needs on the basis of the science and technology development. Such practices of identifying the internal and external needs support the notion need analysis process as mentioned by Sumarmo (2011:1) that the needs assessment is a comprehensive evaluation by identifying the real needs and analying the existing gap.

In one roof Sawohan II primary and Buduran Middle school, the determination of the facilities and infrastructure was done by prioritiing from the most important to the least importany. This is in line with what Imanda (2009:1) says that there are four objectives of the need assessment, which are: (a) screening for identification of the institutional needs, (b) Diagnosis to diagnose the needs on the basis of the priority scale,, (c) program planning through needs assessment, (d) guidance which can be used to consider alternative in attaining the objectives and (e) concencus as a process of learning and considering the limitation in budgetting supports.

In the case of the Nurul Huda Islamic Primary and Middle Schools, the provision of the facilities and infrastructures were done steps by steps. The identification in terms of the internal condition was done by accepting all proposals from the school community members for the certain period of budgetting and integrating the plan and the existing previous condition, integrating the needs for purchasing and the availability of existing budgets, and determining the final facilities and infrastructure provision plan. Furthermore, this school involved lots of stakeholders comprising principals, school committee members, facilities and infrastructure team members, foundation members, teachers, staffs, and parents representatives.

In the case of the one roof school of integrated Sidotopo IV state primary school anfd Surabaya 44 state middle school, the steps to work for the facilities and infrastructure plan were firstly, conducting planning meeting participated by Principalsm teachers, employees, and schools committee members; secondly, formulastin the School Budget Need Plan suited with the identified needs; thirdly, purchasing goods on the basis of the School Budget Need Plan, and fourthly reporting the facilities and infrasturctures condition and purchase to the local/regional department of education. According to Nawawi (1981), educational acilities can be classified into (1) exhausting condition, (2) 
moving condition, and (3) function, which is related to learning. The planning process must be done creatively in which the creativity is the factor, power, influence, and relation to the attainment of educational goals.

Planning the facilities and infrastructures in Sawohan II state primary School and the Buduran state middle schools was done perodically using priority scale, considerinf the availability of fund, and proposing funding to related local and regional department of education in Sidoarjo. The planning process was initiated by designing the budget, formulating provision commitee, and determining the needed goods. The people involved in this process were principals, teachers, school committee, and parent representatives.

b. Provision of the facilities and infrastructures

The proceedures of the facilities and infrastructure provision in the integrated one roof Nurul Huda Islamic primary and middle schools in Sedati, Sidoarjo, were identifying and analyzing the school needs involving coordinator of proposal in each section of the schools, selecting the proposal by designing a program concept and recording the existing facilities and infrastructures, and finally, determining the fund resources and the amount of the school budget. According to Gunawan (2005:5) the management of facilities and infrastructures is the overall process of activities designed and taken action consciously and seriously with continuous guidance in order to be ready for uses in learning process. Such process is aimed at smoothing the learning process.

The facilities and infrastgructure provision in those three schools tended to use dropping technique, purchasing, and borrowing among the primary and middle schools. The limitation of the school budget made the schools unable to fulfill all their needs. . Such condition is suitable to Bafadal's (2004:31) advise that the facilities and infrustructure provision can be done by using (1) dropping, (2) purchasing, (3) obtaining charity, (4) renting or borrowing, and (5) exchanging.

c. Usage of the facilities and infrastructures

The first instant to use the facilities and infrastructure was inventory. This a process of recording and filing for considerinf rhe quantitative and qualitative analysis of the facilities and infrastructure needs. This also involved coding and labelling on the basis of the kinds and dates. In the cases of both integrated one roof schools of Sidotopo IV state primary school and Surabaya 44 state middle school as well as the Sawohan II state primary school and Buduran Middle School in Sidoarjo, the schools used codimg system refefrencing to the date accepted, year of purchase, kinds of goods, origin of the goods, and numbers of goods. The facilities and infrastructures were noted and recorded neatly to show the clear assets of the schools.

The inventory system employed in the integrated one roof Nurul Huda islamic primary and middle school, in Sedati, Sidoarjo, East Java, were identified as follows: (1) recording the school facilities and infrastructure using delivery recdeive book, inventory book, and stock book, (2) making specific code for all official assets, and (3) making report or such official assets.

According to (2013:5) inventory means recording and organizing state properties sistematically, neatly, and structurally based on the certain requirements and guidance. Such opinion suits the way the inventory system was done in integrated one roof Sidotopo 
IV state primary school and Surabaya 44 state middle school as well as the integrated one roof Sawohan II state primary school and Buduran state middle school in Sidoarjo, East Java. On the other hand, the integrated one roof Nurul Huda private islamic primary and middle school developed their own system.

Usage and storage of the facilities and infrastructures were managed to suit the needs of the schools. Those which are not eligible for use are stored in warehouse. The storage of materials or goods were mainly done by identifying the characteristics of the materials wheather they are consumable materials or non consumable materials. The maintenance in the integrated one roof Sawihan II state primary school and Buduran state middle school was done sistematically by checking the materials or goods periodically, doing periodical repair, and propperly doing storage. Such proceedures are in line with what Bafadal (2004:49) says that (1) viewed from the characteristics, maintenance means checking, prventing, light repairing, and heavy repairing, and (2) viewed from the time of mantenance means daily maintenance and peridodical maintenance.

The maintenance process in the integrated one roof private Nurul Huda islamic primary and middle school was done by designing preventif maintenance program, schedulling maintenance, and evaluating maintenance performance. The maintenance became the responsibility of the maintenance team.

\section{d. Supervision/Controlling and Abolition}

Two integrated one roof schools, which were Sidotopo IV state public primary school and Surabaya 44 state public middle school implemented the supervision or controlling and abolition by chategorizing the goods or materials into light and heavy dammages. Those having light damage were repaired. Those having heavy damage and were unable to repair were stored in the wherehouse. The supervision and controlloing was done periodically to ensure that the facilities and infrastructures could be used and mantained. All materials and goods which coud not be repaired were abolished and replaced with the new ones. The lost materials and goods were also abolished. The abolition was done buy having oficial meeting, throwing away in the provided place, burning, or reselling.

The supervision and controlling process in the Nurul Huda private islamic primary and middle school was initiated by having observation, role model, recording, and limitation of authority. Those who involved in supervision were assigned staffs. Teachers, and students controlled by the principals. For materials and goods beimg abolished, the principal made official investigation and report. The foundation members and the assigned staffs provided records of materials or goods being abolished. There was an abilition committee who were responsible to check and to record the materials or goods being abolished.

Accordint to Arifin (2013:8) and Gunawan (2005) the abolition activities are aimed at: (1) preventing and limiting the schools loss due to high cost of maintenance and storage, (2) preventing the wase of cost, (3) freeing the institution from the unbenefited maintenance and security, and (4) easing the inventory load.

The Sidotopo IV state public school determined the criteria for abolishment by identifying the unusable materials or goods, damage materials or goods, and those which could not be 
used for learning process. These were also true for the state public Surabaya 44 midlle school. This school also abolished those over twenty five years of life times.

Results of this research suported the findings of other researchers such as Djatmiko (2006), Krisdianawati (2007), Hasan (2012), Lestari (2012), Widiartini (2012). The facilities and infrastructures turned out to inluence the process o learning Belmo (2012), Suratman (2009), Santoso (2011), Fajariana (2011), Parjono (2014), Bahar (2015), and Arafat (2016). Therefore, it is important to manage and fulfill as required.

\section{Conclusion and Recommendation}

It is concluded that the three schools being research had similarities in managing acilities and infrastructures in terms of (1) needs identification process and proceedures, (2) planning process and documentation resulting the school funding budget plan (3) puschasing the needed facilities and infrastructures. There were also differences in (1) the way the need identification was done, (2) the way planning was done, and the way the provision was done. Meanwile, in terms of the usage, these three schools showed similarity in doing inventgory, storing and doing maintenance, and optimizing the usage. The supervision and controlling as well as the abolition also indicated the similarities. Principly they controlled the materials or goods usage for the benefit of teaching and learning process. In case 1 and 2 they preferred to delegate the process to assigned staffs, whereas, the case 1 preferred to coordinate with foundation members.

It has been suggested that Principals and Foundation members determined the priority scale to fulill the needs for school facilities and infrastructures in order to support efective learning process. The provincial department of education and the regional or district department of education are suggested to pay attention and take care of the needs or facilities and infrustructures among schools in East Java.

\section{References}

Arafat, F. 2016. Hubungan Inovasi Kepala Sekolah, Kelengkapan Sarana Prasarana Sekolah, dan Motivasi dengan Kinerja PNS Guru Sekolah Dasar Negeri di Kota Tegal. Tesis tidak diterbitkan. Malang: Pascasarjana, Universitas Negeri Malang.

Arifin, A.S. 2013. Proses Manajemen Pengembangan Sarana dan Prasarana. (Online), (http://www.lpmpjabar.go.id/?q=node/861), diakses tanggal 30 Januari 2014.

Bafadal, I. 2004. Manajemen Perlengkapan Sekolah. Jakarta: PT Bumi Aksara

Bafadal, I. 2008. Manajemen Perlengkapan Sekolah Teori dan Aplikasinya. Jakarta : PT Bumi Aksara.

Bakar, A. 2015. Hubungan Kualitas Pelayanan, Manajemen Sarana Prasarana, Pemberian Kompensasi, Lingkungan dan Kepuasan Kerja dengan Loyalitas Dosen pada Sekolah Tinggi Agama Islam Negeri (STAIN) Di Sulawesi Selatan. Disertasi tidak diterbitkan. Malang: Pascasarjana Universitas Negeri Malang.

Barnawi \& Arifin, M. 2012. Manajemen Sarana dan Prasarana Sekolah. Jogjakarta: ARRUZZ MEDIA. 
Belmo, K. 2012. Manajemen Sarana dan Prasarana Pada Sekolah Menengah Kejuruan (Studi Multi Situs di SMK Negeri 2 Belu dan SMK Negeri Kakuluk Mesak). Tesis tidak diterbitkan. Malang: Pascasarjana Universitas Negeri Malang.

Bogdan, R. \& Taylor, S.J. 1993. Kualitatif Dasar-Dasar Penelitian. Terjemahan oleh A. Khozin Afandi. Surabaya: Usaha Nasional.

Bogdan, R.C. \& Biklen, S.K. 1998. Qualitative Research for Education: An Introduction to Theory and Methods. Boston: Allyn and Bacon.

Djatmiko, E. 2006. Pengaruh Kepemimpinan Kepala Sekolah dan Sarana Prasarama Terhadap Kinerja Guru SMP Negeri Kota Semarang. Fokus Ekonomi, Volume 1, Nomor 2 Desember 2006, hal 19-30.

Fajariana, E.D.2011. Pengaruh Kualitas Input, Kompetensi Guru, Sarana Prasarana Sekolah terhadap Prestasi Belajar Siswa di Sekolah Menengah Atas Negeri di Situbondo dengan Motivasi Belajar sebagai Variabel Intervening. Tesis tidak diterbitkan, Malang: Pascasarjana Universitas Negeri Malang.

Fattah, N. 2000. Manajemen Berbasis Sekolah. Bandung: Andira Rosdakarya

Fauzi, I. 2008. Administrasi Sarana dan Prasana Pendidikan. (Online). (http://imronfauzi.wordpress.com/2008/06/12/administrasi-sarana-dan-prasaranapendidikan/ ) diakses pada 28 Oktober 2013.

Gunawan, A. 2005. Administrasi Sekolah (Administrasi Pendidikan Micro). Jakarta: PT. Rineka Cipta.

Haryanto. 2012. Pengertian Sarana Pendidikan. (Online), (http://www.belajarpsikologi. com), diakses tanggal 22 Januari 2014.

Hasan, R. 2012. Penyelenggaraan Program SD-SMP Satu Atap Pada Daerah Terpencil dalam Latar Budaya Rumah Betang Kalimantan Tengah (Studi Multi Situs SMPN Satu Atap Mihing Raya, SMPN Satu Atap 2 Kurun, dan SMPN Satu Atap 3 Tewah di Kabupaten Gunung Mas). Disertasi. Tidak Diterbitkan. Malang:Universitas Negeri Malang

Hendra. 2012. Manajemen Sarana dan Prasarana Sekolah. (Online). (http://hendrapgmi.blogspot.com/2012/10/manajemen-sarana-dan-prasarana-sekolah.html) diakses pada 28 Oktober 2013.

Imandala. I. 2009. Konsep Dasar Asesmen. (Online), (http://www.pendidikankhusus.wordpress.com/2009/11/09/konsep-dasar-asesmen/., diakses tanggal 5 Mei 2012)

Imron, A. 1998. Manajemen Peserta Didik di SD: Masalah, Penyebab dan Alternatif Pemecahannya. Jurnal Ilmu Pendidikan 
Kasan, T. 2006. Teori dan Aplikasi Administrasi pendidikan. Jakarta: Studio Press.

Krisdianawati, T.I. 2007. Manajemen Sarana dan Prasarana Pendidikan dalam Meningkatkan Kualitas Pembelajaran PAI di SMP Negeri 02 Turen Kabupaten Malang. Tesis tidak dipublikasikan. Malang: Jurusan Pendidikan Agama Islam, Fakultas Tarbiyah, Universitas Islam Negeri (UIN) Malang.

Lincoln, Y.S. \& Guba, E.G.L. 1985. Naturalistic Inquiry. Beverly Hill, C.A: Sage Publication, Inc.

Mantja, W. 1997. Etnografi: Disain Penelitian Manajemen Pendidikan. Malang: Program Studi Manajemen Pendidikan, Program Pascasarjana, IKIP Malang.

Matin \& Fuad, N. 2014. Manajemen Sarana dan Prasarna Pendidikan, Konsep dan Aplikasinya. Jakarta: PT Rajagrafindo Perkasa.

Miles, M.B. \& Huberman, A.M. 1992. Analisis Data Kualitatif, Buku Sumber tentang Metode-Metode Baru. Diterjemahkan oleh Tjetjep Rohendi Rohidi. Jakarta: Penerbit Universitas Indonesia.

Moleong. 2006. Metodologi Penelitian Kualitatif Edisi Revisi. Bandung: Remaja Rosdakarya.

Nawawi, H. 1981. Administrasi Pendidikan. Jakarta : PT Gunung Agung.

Parjono, 2014. Pengaruh Dukungan Guru, Sarana Prasarana serta Dunia Usaha dan Industri terhadap Kemampuan Beradaptasi Kerja yang Dimediasi oleh Keterampilan Kerja Siswa SMK di Surabaya. Disertasi tidak diterbitkan. Malang: Pascasarjana Universitas Negeri Malang.

Peraturan Menteri Pendidikan Nasional Republik Indonesia Nomor 24 Tahun 2007 tentang Standar Sarana Prasarana untuk Sekolah Dasar/Madrasah Ibti-daiyah (SD/MI), Sekolah Menengah Pertama/Madrasah Tsanawiyah (SMP/MTs), dan Sekolah Menengah Atas/Madrasah Aliyah (SMA/MA).

Santosa. J. 2014. Hubungan Manajemen Sarana dan Prasarana Sekolah, Dampak Sertifikasi Guru, Iklim Sekolah, dan Motivasi Berprestasi Guru dengan Kinerja Guru pada SMK Negeri di Malang Raya. Disertasi tidak diterbitkan. Malang: Pascasarjana Universitas Negeri Malang.

Suratman, B. 2009. Hubungan Kompetensi Manajerial Kepala Sekolah, Ketersediaan Sarana Prasarana, Kapabilitas Mengajar Guru, dan Dukungan Orang Tua, dengan Prestasi Belajar Siswa SMP Negeri di Kota Surabaya. Disertasi tidak diterbitkan. Malang: Pascasarjana, Universitas Negeri Malang.

Surya, M. 2010. Alternatif Program Pengentasan Wajib Belajar 9 Tahun. (Online), (http://www.multiply.com,/), diakses tanggal 13 Oktober 2013. 
Management of facilities and infrastructures at one roof schools....

Ulfatin, N. 2004.Penelitian Kualitiatif. Malang: Fakultas Ilmu Pendidikan Universitas Negeri Malang.

Undang-Undang Dasar Republik Indonesia Tahun 1945. Jakarta:Citra Umbara

Undang-Undang Nomor 20 Tahun 2003, Tentang Sistem Pendidikan Nasional. Jakarta: Depdiknas

Wiyono, B.D. 2007. Metodologi Penelitian Kualitatif. Malang: Jurusan Administrasi Pendidikan, Fakultas Ilmu Pendidikan, Universitas Negeri Malang.

Yin, R. K. 1984. Case Study Research: Design and Methods. San Francisco, California: Sage Publications, Inc. 